Journal of Science Education Research

Journal homepage: www.journal.uny.ac.id/jser

\title{
The Effectiveness of Inductive and Deductive Strategies to Improve Motivation and Achievement in Learning Science of Junior High School Students
}

\author{
Allesius Maryanto $^{1 *}$, Mundilarto ${ }^{2}$ \\ ${ }^{1,2}$ Study Program of Science Education, Faculty of Mathematics and Natural Sciences, Universitas Negeri Yogyakarta \\ Corresponding Author. Email: maryanto.al@gmail,com
}

Keywords:
effectiveness,
science instruction,
inductive strategy,
deductive strategy,
academic
achievement and
learning motivation

\section{Keywords:}

effectiveness, inductive strategy, deductive strategy, achievement and learning motivation

\begin{abstract}
This study aimed to determine the effectiveness of teaching using the inductive and deductive strategies on the improvement of learning achievement and motivation students. This study was a quasi-experimental study, involved all students of class IX of SMPN 2 Sentolo, Kulonprogo in the academic year of 2010/2011. Sample was established using the purposive sampling technique, two science classes each of 32 students were taught using the inductive and deductive strategy. The data were gathered using a pretest and posttest. The students' achievement was measured using a multiple choice test and their motivation were measured using a questionnaire and observation sheets. The results show that: (1) there is a difference of science instruction through deductive and inductive strategies on improving learning achievement, which is supported by Independent Samples Test in the ttest column for Equality of Means, score value of sig. (2 tailed) is 0,026 ; (2) there is no differences of deductive and inductive strategies on improving students' motivation, which is supported by t-test column for Equality of Means, score value of sig. (2 tailed) is 0,153 ; (3) there is a significant correlation of motivation on learning science and science achievement, which is shown by the value of coefficient of correlation 0,736 .
\end{abstract}

\section{INTRODUCTION}

A goal of science learning in schools is to improve the competency of students in thinking, acting and behaving like a scientist. This goal is in accordance with the characteristics of science which is an experimental science and much associated with natural symptoms that are often found by students in everyday life. Teachers are required to be creative and innovate in finding and implementing the models and choosing appropriate learning strategies aiming to reach the goals of learning science in schools.

The weak ability of students in term of scientific literacy is observed from the results of the TIMSS (Trends In International Mathematics and Science Study) study held in every four years starting in 1995. TIMSS provides information on the assessment of science learning outcomes at international level for students in the eighth grade, which was attended by 54 countries in TIMSS list on 2011. TIMSS in 2011 showed Indonesia was ranked 49 out of 54 countries with an average score of 406. This result proved that Indonesian students in learning science on average only able to remember facts, terminology, and laws of science, but they are lacking in using the knowledge to evaluate, analyze, and solve the problems in daily life. This predicate also reflects the Indonesian education system that is currently not yet providing good quality in the world of education.

In overcoming the weaknesses of education in Indonesia, the government has tried to improve the quality of education, such as improving the curriculum. Curriculum improvement is carried out through a competency-based curriculum or curriculum 2004 as a refinement of the curriculum 1999 and the implementation of KTSP (Education Unit Level Curriculum) as the application of content standards that emphasize the role of educators in developing standard material and building student competencies, especially in the fields of science. In this case, educators are required to be creative, professional, able to develop the learning strategies 
that are oriented towards increasing the intensity of student involvement effectively in the learning process.

Learning innovation is needed to create quality learning due to learning innovation is a useful effort to change or improve the implementation of the learning process. Educators strive to the maximum and creatively to provide strategies or interesting way to attract the students. A learning process should be meaningful, integrated, and challenged in term of providing the learning efforts of students. This type of learning is commonly referred to as active learning, oriented towards PAKEM (Productive, Active, Creative, Effective and Enjoyable).

The fact found in schools does not achieve yet with the determined goal. Moreover, science learning still has many problems, such as lack of learning innovations; one of them is using learning strategies. The learning model often applied is the conventional model (lecture model). Conventional models are less able to improve students' thinking skills and learning motivation. Here, the students are passive during lessons.

The results of preliminary observations at SMP 2 Sentolo showed that, in general, delivering of science material conducted by educators was more dominated and emphasized verbally to students with adding a little question and answer session. The interviews with educators of science found a fact that during the learning process students lack preparation in following the learning and not actively involved in the learning process. On the other hand, educators pay less attention to the interests and motivations within students, so the potential of students has not developed optimally. During the learning activities, students feel bored and lack enthusiasm, and the classroom atmosphere seems boring, less organized and not conducive. Learning science in a such atmosphere is more blocking the ability than developing abilities.

Science learning in schools should not be directed solely to preparing students to enter a higher level of education. According to Rutherford \& Ahlgren Rutherford (1990: 188) stated that:

"Science, mathematics, and technology are defined as much by what they do and how they do it as they are by the result by achieve. To understand them as ways of thinking and doing, as well as bodies of knowledge, requires that students have some experience with the kind of thought and action that are typical of those filds. Teachers, therefore, should do the following :

Sound teaching usually begins with questions and phenomena that are interesting and familiar to studens, not with abstractions or phenomena outside their range of perception, understanding or knowledge. Students need to get acquainted with the things around them - including devices, organism, materials, shapes, and numbersand to observe them, collect them, handle them, describe them, become puzzled by them, ask questions about them, argue about them, and then to try to find answer to their questions. "

But the statement of Rutherford \& Ahlgren (1990: 188) is not in accordance with the results of observations and interviews at SMP Negeri 2 Sentolo due to the science learning is more often carried out with method of lecturing and questions and answers. This fact is also not in accordance with Law No. 20 on National Education System of article 40 and Government Regulation No. 19 on national education standard of article 19, which states that the learning process in educational units is held interactively, inspirational, fun, challenging, motivating students to actively participate, and providing sufficient space for initiatives, creativity, and independence based on talents, interests, and the physical and psychological development of students.

An effort to overcome these problems is by improving the learning process in the classroom. Through meaningful learning and motivates students during science learning, the students will feel meaningful learning.

Chiappetta \& Koballa (2010: 133) stated that:

"The inductive strategy provides student with learning situations in which they can discover a concept or principle through experiences in the laboratory, field, or classroom. With in this strategy, the attributes in instances of an idea are encountered first by the learner, followed by naming and discussing the idea under study. The inductive approach provides students with concrete experience whereby they obtain data from objects and events, which in turn gives them a foundation upon which to anchor information and build new knowledge. Inductive activities can be thought of as an experience-before-vocabulary approach to learning.

Then, Chiappetta \& Koballa (2010:133), argued that:

"In contrast to the inductive strategy, deductive thinking in used often in science courses. It is the traditional lecture/laboratory sequence with which most science majors are familiar. This strategi is commonly observed in the middle school through college science teaching. With the deductive strategy, a concept or priciple is difined and discussed using appropriate labels and terms, followed by experience to illustrate the idea. The deductive approach is a vocabulary-beforeexperience model of teaching where lecture and discussion precede firsthand or concrete experience. It can also involve hypothetical-deductive 
thinking,whereby the learner generates ideas to be tested or discovered or the teacher makes explicit what is the students should be looking for in the laboratory or field".

The use of inductive or deductive learning strategies aims to develop the students' thinking skills. Teachers can combine the strategy with natural phenomena in the environment where students live as learning resources. And then, students will be more motivated to learn science. Students with high learning motivation will feel fun, interested and passion for learning to achieve the maximum result of learning achievement.

Teachers as educators must know the need of the student and must able to grow and develop the motivation of students. Giving good motivation from the teacher will be able to make students aware of the benefits of learning. So, they can achieve learning goals. Giving motivation in learning is also expected to build a passion for learning, especially for students who are lazy to learn as a result of negative influences from outside factor. Finally, it might form habits of fun learning and impact on the increased of learning achievements.

According to Aunurrahman (2011: 177), internal factors influencing the learning process of students are characteristics of students, attitudes during learning, motivation to learn, concentration during learning, reading the teaching materials, exploring learning outcomes, self-confidence, and learning habits. External factors influencing the learning process of students are teacher, social environment (including peers), curriculum, and facilities and infrastructure. By understanding the internal and external factors, the teacher might understand the learning problems that generally occur to students aiming the learning activities can increase students' motivation, not the other way around.

Low motivation may be caused by a lot of factors, such as low self-esteem, laziness to learn, lack of attention from parents or people around, no encouragement, and others. Based on the description, it needs to have research to determine the effectiveness of inductive and deductive learning strategies in terms of aspects of learning achievement and motivation. By understanding the two learning strategies, hoped the teachers can use active, creative, effective, fun and meaningful learning strategies.

Based on the background, the problem formulations are:

1. Are there significant differences in the effectiveness of teaching using inductive and deductive strategies on the improvement of learning science learning achievement of students on grade IX at SMPN 2 Sentolo?
2. Are there significant differences in the effectiveness of teaching using inductive and deductive strategies on the improvement of learning motivation of students on grade IX at SMPN 2 Sentolo?

3. Is there a significant relationship between learning motivation and students' achievement teaching using inductive and deductive strategies on the improvement of learning motivation of students on grade IX at SMPN 2 Sentolo?

The research objectives of the study are:

1. Differences in the effectiveness of teaching using inductive and deductive strategies on the improvement of learning science learning achievement of students on grade IX at SMPN 2 Sentolo.

2. Differences in the effectiveness of teaching using inductive and deductive strategies on the improvement of learning motivation of students on grade IX at SMPN 2 Sentolo.

3. Relationship between learning motivation and students' achievement teaching using inductive and deductive strategies on the improvement of learning motivation of students on grade IX at SMPN 2 Sentolo.

A deductive strategy is a learning strategy using deductive reasoning, which is theoretical reasoning leads to reality or reasoning begins with the explanation of general things to specific things. An inductive strategy is a learning strategy using inductive reasoning, which are reasoning based on various cases, facts, then leads to basic principles or from specific to general thing. Motivation might mean like a person's strength which can lead to a level of persistence (persistence persistently) and enthusiasm in carrying out an activity, both intrinsic and extrinsic motivation. Learning achievement is the result of learning activities by conducting a series of assessments carried out by educators aiming to monitor the process and progress of student during the learning and to increase the effectiveness of learning activities.

\section{METHOD}

The particular research used a quantitative approach with quasi-experiment and posttest control group design. The research design is presented in table 1 .

Table 1

\begin{tabular}{|c|c|c|}
\hline \multicolumn{3}{|c|}{ Postest Control Group Design } \\
\hline Group & Treatment & Postest \\
\hline Inductive & $X_{1}$ & $\mathrm{O}_{1}$ \\
\hline Deductive & $\mathrm{X}_{2}$ & $\mathrm{O}_{2}$ \\
\hline
\end{tabular}


Where :

$\mathrm{O}_{1}$ : posttest of inductive group

$\mathrm{O}_{2}$ : posttest of deductive group

$\mathrm{X}_{1}$ : Learning using inductive strategy

$\mathrm{X}_{2}$ : Learning using deductive strategy

The study conducted at SMP N 2 Sentolo, Kulon Progo Regency, Special Region of Yogyakarta in the odd semester of 2011/20012 academic year. The population was the entire students of grade IX of SMP Negeri 2 Sentolo Kulon Progo in the academic year 2010/2011 which consisted of 4 parallel classes with a total of 128 students. Purposive sampling used to select the sample.

The particular study used a sample from two classes:

1. The class given a treatment of learning using Deductive strategy is class IX B. Then, this group is called the deductive class. Then, this group is called the deductive class.

2. The class given a treatment of learning using Inductive strategies is class IX C. Then, this group is called the inductive class.

The data were:

1. Data from questionnaire on learning motivation of student given to grade IX on science learning both Deductive strategies (class IX B) and Inductive strategies (class IX C).

2. Data of science learning outcomes obtained through cognitive achievement tests of students in multiple choice tests. The purpose of this test was to measure the cognitive abilities of students for both deductive and inductive classes.

3. Data the questionnaire results on the student's response to learning were obtained by giving learning response questionnaires to the grade IX Science class both Deductive strategies (class IX B) and Inductive strategies (class IX C).

The instruments in this study were learning instruments tools (Lesson Plan \& Student Worksheet) and instruments for data collection of variable data (science learning achievement tests, motivation questionnaires \& implementation sheets for student worksheet). The entire instrument was validated by the material expert to find out whether the instrument is feasible or not. The validity and reliability of the instruments from the empirical test were known with the help of the QUEST program.
In this particular study, the data were analyzed according to the research flow:

1. Validation analysis of research instruments according to material experts.

2. Analysis of science learning achievement.

3. Analysis of science learning motivation.

4. Analysis of LKS (students' worksheet) implementation observation sheet.

5. Assumptions test or prerequisites (normality test, homogeneity test).

6. Hypothesis test (t-test and correlation test).

\section{RESULT}

Data of the particular study were data on science learning achievement and data on science learning motivation of students on grade IX at SMP N 2 Sentolo 2 on dynamic electrical material treated with Inductive and Deductive strategies.

The research instruments have validated by experts to obtain consideration, truth, feasibility, and quality of instruments both in term of writing and verbally. The instruments validated by experts were: Lesson Plan (inductive and deductive strategy), Student Worksheet (inductive and deductive strategy), multiple choice questions, and questionnaires of motivation and LKS implementation observation sheets. The assessment carried out by an expert, Dr. Dadan Rosana (lecturer at the Department of Physics Education at FMIPA UNY) and studied to obtain recommendations by Prof. Dr. Mundilarto as an advisor.

The summary of the assessment results is presented in Table 2:

Table 2

Result of Material Expert Assessment

\begin{tabular}{llll}
\hline No & Assessed Aspect & Score & Category \\
\hline 1 & Lesson Plan & 89 & Good \\
2 & Student Worksheet & 45 & Good \\
3 & Multiple Choice & 60 & Very Good \\
4 & $\begin{array}{l}\text { Questionnaire or } \\
\text { science learning }\end{array}$ & 59 & Very Good \\
& motivation & & \\
5 & LKS & 26 & Very Good \\
& implementation & & \\
observation sheets & & \\
\hline
\end{tabular}

The research data consisted of data on student achievement tests and student motivation questionnaires using valid and reliable instruments.

The following data are presented for each class, namely:

1. Deductive Class (IXB)

Data of research result obtained on science learning through deductive strategy, include; 
(a) Data on learning achievement

Data on learning achievement consists of test results data for science learning with deductive strategy using valid and reliable of 50 multiple choice questions. There were 32 students followed the test. The summary of the attachments is presented in table 3 .

Table 3

Score of Science Learning Achievement Student of Deductive Class

\begin{tabular}{lll}
\hline Score & $\begin{array}{l}\text { Correct } \\
\text { Answer }\end{array}$ & Score \\
\hline Maximum & 42 & 84 \\
Minimum & 27 & 54 \\
Mean & 35,28 & 70,56 \\
\hline
\end{tabular}

Based on the mastery learning criteria (KKM) in SMP N 2 Sentolo on 65, the result is presented in Table 4.

Table 4

Student Learning Mastery

Deductive Class

\begin{tabular}{llll}
\hline No & $\begin{array}{l}\text { Mastery } \\
\text { Learning }\end{array}$ & Count & Percentage \\
\hline 1 & Complete & 26 & 81,25 \\
2 & Incomplete & 6 & 18,75 \\
\hline
\end{tabular}

(b) Data on Science learning motivation

Data on science learning motivation was obtained through a questionnaire on science learning motivation. The questionnaire of science learning motivation consisted of 29 valid and reliable items given to 32 students. Based on predetermined criteria, student motivation is classified into 5 levels: very high (122 - 145), high (99 - 121), moderate (76 - 98), low (53 - 75) and very low (2952). The summary of the attachments is presented in Table 5.

Table 5

Score of Science learning motivation Deductive Class

\begin{tabular}{llll}
\hline $\begin{array}{l}\text { Score of } \\
\text { motivation }\end{array}$ & Classification & Count & $\%$ \\
\hline $122-145$ & Very High & 4 & 12,5 \\
$99-121$ & High & 26 & 81,25 \\
$76-98$ & Moderate & 2 & 6,25 \\
$53-97$ & Low & 0 & 0 \\
$29-52$ & Very Low & 0 & 0 \\
\hline
\end{tabular}

(c) Data of implementation observation sheet of students' worksheet

Data of implementation observation sheet of students' worksheet (LKS) are the data obtained through observation during the science learning activities with deductive strategies. It conducted by 4 observers on 8 groups in each class. Observations used an observation sheet consisting of 12 items. Each observer observed two groups. The results of observations from 4 observers summed up and calculated the mean. So, it obtained the data of LKS implementation for the deductive class. The summary of the observations is presented in Table 6.

Table 6

Result of Implementation Observation Sheet of students' worksheet (LKS) on Deductive Class

\begin{tabular}{llll}
\hline No & Activity & Mean & Category \\
\hline 1 & LKS & & Very well \\
& Deductive 1 & 41,25 & implemented \\
2 & LKS & 41,125 & $\begin{array}{l}\text { Very well } \\
\text { implemented }\end{array}$ \\
& Deductive 2 & & $\begin{array}{l}\text { Very well } \\
\text { implemented }\end{array}$ \\
LKS & 40,125 & $\begin{array}{l}\text { Very well } \\
\text { implemented }\end{array}$ \\
Average & $\mathbf{4 0 , 8 3}$ & \\
\hline
\end{tabular}

2. Inductive Class (IXC)

Data of research result obtained on science learning through inductive strategy were: learning achievement, learning motivation, and LKS implementation observation sheets.

(a). Data of learning achievement

Data on learning achievement consists of test results data for science learning with inductive strategy using valid and reliable of 50 multiple choice questions. There were 32 students followed the test. The summary of the attachments is presented in table 7 .

Table 7

Score of Science Learning Achievement Student of Inductive Class

\begin{tabular}{lll}
\hline Score & $\begin{array}{l}\text { Correct } \\
\text { Answer }\end{array}$ & Score \\
\hline Maximum & 44 & 88 \\
Minimum & 19 & 38 \\
Mean & 31,91 & 63,81 \\
\hline
\end{tabular}

Based on the mastery learning criteria (KKM) in SMP N 2 Sentolo on 65, the result is presented in Table 8. 
Table 8

Student Learning Mastery Inductive Class

\begin{tabular}{llll}
\hline No & $\begin{array}{l}\text { Mastery of } \\
\text { learning }\end{array}$ & Count & $\%$ \\
\hline 1 & Complete & 18 & 56,25 \\
2 & Incomplete & 14 & 43,75 \\
\hline
\end{tabular}

\section{(b) Data of science learning motivation}

Data on science learning motivation was obtained through a questionnaire on science learning motivation. The questionnaire of science learning motivation consisted of 29 valid and reliable items given to 32 students. Same with the deductive learning, learning motivation on inductive strategy class classified into 5 levels. The summary of the attachments is presented in Table 9.

Table 9

Score of Science learning motivation Inductive Class

\begin{tabular}{llll}
\hline $\begin{array}{l}\text { Score of } \\
\text { motivation }\end{array}$ & Classification & Count & $\%$ \\
\hline $122-145$ & Very High & 4 & 12,5 \\
$99-121$ & High & 26 & 81,25 \\
$76-98$ & Moderate & 2 & 6,25 \\
$53-97$ & Low & 0 & 0 \\
$29-52$ & Very Low & 0 & 0 \\
\hline
\end{tabular}

(c) Data of implementation observation sheet of students' worksheet

Data of implementation observation sheet of students' worksheet (LKS) are the data obtained through observation during the science learning activities with deductive strategies. It conducted by 4 observers on 8 groups in each class. Observations used an observation sheet consisting of 12 items. Each observer observed two groups. The results of observations from 4 observers summed up and calculated the mean. So, it obtained the data of LKS implementation for the deductive class. The summary of the observations is presented in Table 10.

Table 10

Result of Implementation Observation Sheet of students' worksheet on Inductive Class

\begin{tabular}{|c|c|c|c|}
\hline \multirow{3}{*}{$\begin{array}{l}\text { No } \\
1\end{array}$} & Activity & Mean & Category \\
\hline & LKS & 40,25 & Very well \\
\hline & Inductive 1 & & implemented \\
\hline 2 & $\begin{array}{l}\text { LKS } \\
\text { Inductive } 2\end{array}$ & 39,73 & $\begin{array}{l}\text { Very well } \\
\text { implemented }\end{array}$ \\
\hline 3 & $\begin{array}{l}\text { LKS } \\
\text { Inductive } 3\end{array}$ & 40,25 & $\begin{array}{l}\text { Very well } \\
\text { implemented }\end{array}$ \\
\hline \multicolumn{2}{|c|}{ Mean } & 40,08 & $\begin{array}{l}\text { Very well } \\
\text { implemented }\end{array}$ \\
\hline
\end{tabular}

\section{Hypothesis Test}

Hypothesis test consisted of two, namely: (a) ttest and (b) correlation test. Calculation of t-test and correlation test carried out with the help of SPSS 17. The steps of hypothesis test were:

\section{a. First Hypothesis}

The first hypothesis in this study was:

$\mathrm{H}_{\mathrm{o}}$ : There is no significant difference in the effectiveness of teaching using inductive and deductive strategies on the improvement of learning science learning achievement of students on grade IX at SMPN 2 Sentolo.

$\mathrm{H}_{1}$ : There is significant difference in the effectiveness of teaching using inductive and deductive strategies on the improvement of learning science learning achievement of students on grade IX at SMPN 2 Sentolo.

Based on the results of t-tests aiming to find out the differences between those two strategies in improving learning achievement are presented in Table 11.

Table 11

Summary of Result of $t$-test

Science learning achievement

\section{Group Statistics}

\begin{tabular}{|c|c|c|c|}
\hline STRATEGY & $\mathrm{N}$ & Mean & $\begin{array}{ll}\text { Std. } & \text { Std. } \\
\text { Devi } & \text { Error } \\
\text { ation } & \text { Mean }\end{array}$ \\
\hline ACHIEVEM 1 & 32 & 70.56 & 8.3511 .476 \\
\hline ENT & 32 & 63.81 & 14.562 .575 \\
\hline
\end{tabular}

\section{Independent Samples Test}

Based on the output of SPSS 17, on the Statistics Group stated that the number of students for both classes was 32, and the mean for class 1 (deductive strategy) was 70.56 and for class 2 (inductive strategy) was 63.81. On the output of the Independent Samples of t-test for Equality of Means, score sig. (2 tailed) was 0.026. Based on the criteria, if the value of sig. ( 2 tailed) $<0.05$, Ho is rejected. Means, there is a significant difference in the science achievement obtained by students on learning science using deductive strategies and inductive strategies.

Based on the conclusion, the deductive strategy is more effective in improving science learning achievement than inductive strategies. The effectiveness of the deductive strategy was proven from the number of students who complete the learning in the material of dynamic electricity; 26 students or $81.25 \%$ of the deductive strategy compare to 18 students or $56.25 \%$ in inductive strategy class. 


\section{b. Second Hypothesis}

$\mathrm{H}_{\mathrm{o}}$ : There is no significant difference in the effectiveness of teaching using inductive and deductive strategies on the improvement of motivation of students on grade IX at SMPN 2 Sentolo.

$\mathrm{H}_{1}$ : There is significant difference in the effectiveness of teaching using inductive and deductive strategies on the improvement of motivation of students on grade IX at SMPN 2 Sentolo.

The result of t-test to determine the motivation improvement is presented in table 12 .

Table 12

Summary of $t$-test on motivation of science learning
$\mathrm{H}_{1}$ : There is significant correlation between learning motivation and learning achievement using inductive and deductive strategies on grade IX at SMPN 2 Sentolo.

Hypothesis test carried out in 3 steps:

(1). Correlation between learning motivation and achievement for deductive strategy.

Analysis result of the correlation between learning motivation and achievement for a deductive strategy using SPSS 17 is presented in table 13.

Table 13

Summary of Analysis of the correlation between motivation and achievement on science learning of Deductive Class

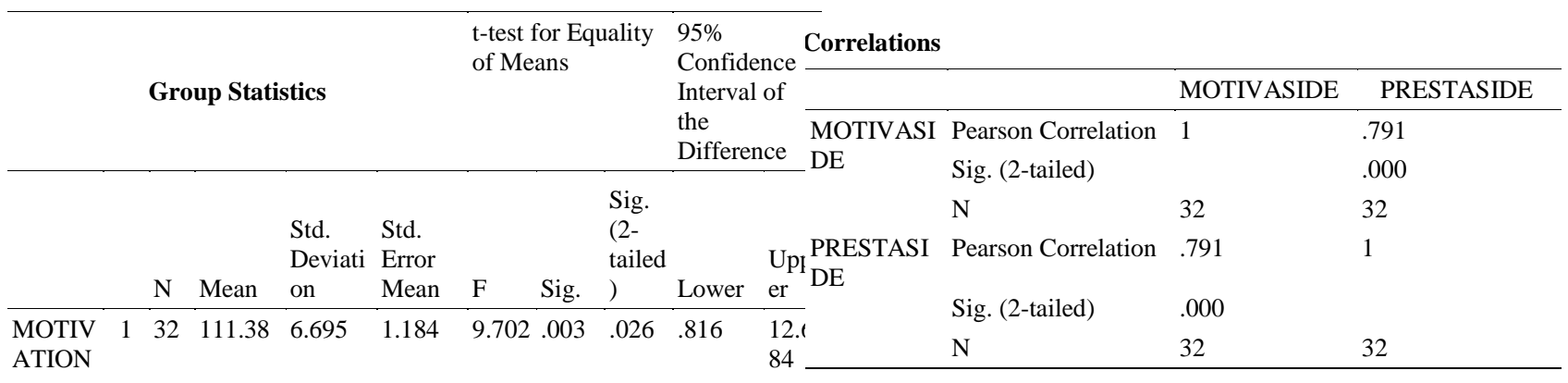

$\begin{array}{lllll}2 & 32 & 108.50 & 9.038 & 1.598\end{array}$

Based on the output of SPSS 17, on the Statistics Group stated that the number of students for both classes was 32, and the mean for class 1 (deductive strategy) was 111.38 and for class 2 (inductive strategy) was 108.50 . On the output of the Independent Samples of t-test for Equality of Means, score sig. (2 tailed) was 0.153. Based on the criteria, if the value of sig. ( 2 tailed) $<0.05$, Ho is accepted. Means, there is no a significant difference in the science learning motivation of students on learning science using deductive strategies and inductive strategies.

There is no a significant difference in the science learning motivation of students on learning science using deductive strategies and inductive strategies because (1) learning habit with lecturing method effect on those strategies can improve the motivation of students, and (2) lack of understanding toward the important to filled out the questionnaire of learning motivation truly and remarkably to support the learning.

\section{c. Third Hypothesis}

$\mathrm{H}_{\mathrm{o}}$ : There is no significant correlation between learning motivation and learning achievement using inductive and deductive strategies on grade IX at SMPN 2 Sentolo.
Based on the output of SPSS 17, on the Correlation stated that the number of students for the deductive class was 32 and the score sig. (2 tailed) was 0.05 . Then, Ho is rejected. Means, there is a significant correlation between learning motivation and learning achievement using deductive strategies with a correlation coefficient of 0.791 (strong).

(2). Correlation between motivation and achievement of science learning for inductive strategy.

Analysis result of the correlation between learning motivation and achievement for inductive strategy using SPSS 17 is presented in table 14 .

Table 14

Summary of Analysis of the correlation between motivation and achievement on science learning of Inductive Class 
Correlations

\begin{tabular}{|c|c|c|c|}
\hline & & $\begin{array}{l}\text { MOTIVA } \\
\text { TION }\end{array}$ & $\begin{array}{l}\text { ACHIEVE } \\
\text { MENT }\end{array}$ \\
\hline \multirow[t]{3}{*}{ MOTIVATION } & Pearson Correlation & 1 & .736 \\
\hline & Sig. (2-tailed) & & .000 \\
\hline & $\mathrm{N}$ & 64 & 64 \\
\hline \multirow[t]{3}{*}{ ACHIEVEMENT } & Pearson Correlation & .736 & 1 \\
\hline & Sig. (2-tailed) & .000 & \\
\hline & $\mathrm{N}$ & 64 & 64 \\
\hline
\end{tabular}

Based on the output of SPSS 17, on the Correlation stated that the number of students for the deductive class was 32 and the score sig. (2 tailed) was 0.000 . Then, Ho is rejected. Means, there is a significant correlation between learning motivation and learning achievement using inductive strategies with a correlation coefficient of 0.705 (strong).

(3). Correlation between motivation and achievement of science learning for both strategies (inductive and deductive strategy)

Analysis result of the correlation between learning motivation and achievement for both strategies (inductive and deductive strategy) using SPSS 17 is presented in table 15.

Table 15

Summary of Analysis of the correlation between motivation and achievement on science learning for both strategies (inductive and deductive strategy)

Correlations

\begin{tabular}{llll}
\hline & & MOTIVASIIN & PRESTASIIN \\
\hline MOTIVASIIN & Pearson Correlation & 1 & .705 \\
& Sig. (2-tailed) & & .000 \\
& $\mathrm{~N}$ & 32 & 32 \\
PRESTASIIN & Pearson Correlation & .705 & 1 \\
& Sig. (2-tailed) & .000 & \\
& $\mathrm{~N}$ & 32 & 32 \\
\hline
\end{tabular}

Based on the output of SPSS 17, on the Correlation stated that the number of students for both classes (deductive and inductive class) was 64 and the score sig. (2 tailed) was 0.000 . Then, Ho is rejected. Means, there is a significant correlation between learning motivation and learning achievement with a correlation coefficient of 0.736 (strong).

The results of correlation analysis showed that between science learning motivation and science learning achievement there is a strong correlation $(r=0.736)$, this also occurred in correlation analysis separately, based on deductive strategy $(r=0.791)$ or inductive strategy $(r=0.705)$.
The third hypothesis was analyzed by Karl Pearson correlation analysis or the product-moment coefficient correlation. Based on the Pearson correlation analysis using SPSS 17, the results showed that there is a strong correlation between motivation and achievement of science learning $(r=$ 0.736). This also happened in (1) deductive strategy class, correlation between motivation and achievement of science learning correlated strongly with a correlation coefficient of $r=0.791$, and (2) inductive strategy class, the correlation between motivation and achievement of science learning correlated strongly with a correlation coefficient of $r$ $=0.705$. Therefore, this research found out that between motivation and achievement of science learning has positive and strong correlation.

In this particular study, the learning effectiveness of each class was seen from the achievement of learning objectives. The criteria for achievement of learning objectives were: (1) the KKM achievement (minimum completeness criteria) is $75 \%$ for learning achievement and (2) motivation at least reaches a high motivation classification in each class of $75 \%$ for learning motivation.

The results of learning effectiveness seen from the achievement of learning objectives with the determined criteria are presented in Table 16.

Table 16

Summary of Science Learning Effectiveness

\begin{tabular}{|c|c|c|c|}
\hline \multirow[b]{2}{*}{ No } & \multirow[b]{2}{*}{ Class } & \multicolumn{2}{|c|}{ Learning Effectiveness } \\
\hline & & $\begin{array}{l}\text { Science } \\
\text { learning } \\
\text { achievement }\end{array}$ & $\begin{array}{l}\text { Science } \\
\text { learning } \\
\text { motivation }\end{array}$ \\
\hline 1 & $\begin{array}{l}\text { Deductive } \\
\text { Strategy }\end{array}$ & $\begin{array}{l}\text { Students } \\
\text { obtained } \\
\text { score higher } \\
\text { than KKM is } \\
81.25 \% \quad(28 \\
\text { students of } \\
32)\end{array}$ & $\begin{array}{l}\text { Students with } \\
\text { motivation of } \\
\text { very high and } \\
\text { high } \\
\text { Jumlah siswa } \\
93.25 \% \\
\text { students } \\
32)\end{array}$ \\
\hline 2 & $\begin{array}{l}\text { Inductive } \\
\text { Strategy }\end{array}$ & $\begin{array}{l}\text { Students } \\
\text { obtained } \\
\text { score higher } \\
\text { than KKM is } \\
56.25 \% \quad(18 \\
\text { students of } \\
32)\end{array}$ & $\begin{array}{l}\text { Students with } \\
\text { motivation of } \\
\text { very high and } \\
\text { high are } \\
\text { Jumlah siswa } \\
93.25 \% \text { (30 } \\
\text { students of } \\
32)\end{array}$ \\
\hline
\end{tabular}


Based on Table 16, in deductive strategy has completed because the number of students who have obtained scores higher than KKM is $81.25 \%$ and $93.25 \%$ of students with high motivation. In contrast, in inductive strategy, the number of students who have obtained scores higher than $\mathrm{KKM}$ is $56.25 \%$. But, classically, the result has not yet achieved the learning objectives even $93.25 \%$ of students have very high motivation and high motivation.

Based on the effectiveness criteria, science learning with deductive strategy is more effective than inductive strategy.

The results of the hypothesis test showed a correlation between motivation and learning achievement of students. The finding is in line with Ghulam Hamdu and Lisa Agustina (2011: 95) in a study of the effect of learning motivation on science learning achievement in elementary schools. The research concluded that there is an influence of learning motivation on learning achievement in science.

Meanwhile, two other researchers; (1) Lawson (2003) conducted research on previous scientific discoveries along with logical thinking about the findings that showed, science is a deductivehypothetical. Scientists always involve deductivehypothetical in each process of its discovery, and (2) Taufiq and Ketang Wiyono (2009: 647), concluded that the increase in students' generic science skills on balance material using deductive-hypothetical learning cycle models is higher than conventional learning. These are in accordance with the research that the strategy influences the learning achievement of science and correlated with the motivation to learn science.

The optimal results in this study have not achieved, because (1) limited time affected the choice of learning material, (2) the limited number of tools affected a group consists of 4 students, (3) limited time of learning which made some groups have not completed fully their assignments, (4) learning habits of students tend to be passive, and only listen and take notes, which quite difficult to change students to be more active, and (5) limited on observations during learning which some activities of students and teachers have not documented yet.

\section{CONCLUSION}

\section{Conclusions}

Based on the analysis results of hypothesis test and the discussions, the particular article concluded:

1. There is significant difference in the effectiveness of teaching using inductive and deductive strategies on the improvement of learning science learning achievement of students on grade IX at SMPN 2 Sentolo.

2. There is no significant difference in the effectiveness of teaching using inductive and deductive strategies on the improvement of learning motivation of students on grade IX at SMPN 2 Sentolo.

3. There is significant correlation between learning motivation and learning achievement of science using inductive and deductive strategies on grade IX at SMPN 2 Sentolo.

\section{Suggestions}

The particular article proposed suggestions to improve science learning;

1. The principal should always encourage/motivate Science teachers conducting learning innovations through the use of learning models.

2. Science teachers should always conduct learning innovations using learning models to facilitate the learning process to achieve maximum results. Aiming to create an effective learning process, the article recommended the use of the learning model that lead the individual of students individually beside in groups.

3. Experts and researchers conduct and develop more intensive research to improve the instruments of synectic learning and heuristics vee to create learning tools with scientific methodological methods as a product of research.

\section{REFERENCES}

(1996). Nasional Science Education Standards. USA. National Academy of Science.

http://www.nap.edu/catalog/4962.html accessed on 27 September 2010 at 7.59 am.

(2003). Undang-Undang, Nomor 23, Tahun 2003, tentang Sistem Pendidikan Nasional.

(2005). Peraturan Pemerintah Nomor 19 Tahun 2005 tentang Standar Nasional Pendidikan

Aunurrahman. (2011). Belajar dan Pembelajaran. Bandung: Penerbit Alfabeta

Chiapetta, Eugene L \& Koballa Jr, Thomas R. (2010). Science Intruction in The Middle and Secondary Schools Developing Fundamental Knowledge and Skills. Boston: Pearson Education Inc.

Ghulam Hamdu \& Lisa agustina. (2011). Pengaruh Motivasi Belajar Siswa Terhadap Prestasi 
Allesius Maryanto, Mundilarto/ JSER 2019, 3(1), 10

belajar IPA di Sekolah dasar. Jurnal Penelitian Pendidikan, 12 (1).

Lawson, Anton E. (2003). Allchin's Shoehorn, or Why Science is Hypotheco-Deductive. Netherlands: Kluwer Academic Publisher.

Rutherford, F. James \& Ahlgren, Andrew (1990). Science. New York: Oxford University Press.

Taufig \& Ketang Wiyono. (2009). The Application Of Hypothetical Deductive Learning Cycle
Learning Model To Improve Senior High School Students' Science Generic Skills On rigid Body Equllibrium. Proceeding Of The Third In International Seminar On Science Education "Challenging Science Education in The Digital Era". 